\title{
Efficacy of Moringa oleifera Seed Husk as Adsorptive Agent for Trihalomethanes from a Water Treatment Plant in Southwestern, Nigeria
}

\author{
Aderonke Adetutu Okoya ${ }^{D},{ }^{1}$ Olasunkanmi Olalekan Olaiya ${ }^{(D)}{ }^{1}$ \\ Abimbola Bankole Akinyele, ${ }^{1}$ and Nnenneh Oruada Ochor ${ }^{2}$ \\ ${ }^{1}$ Institute of Ecology and Environmental Studies, Obafemi Awolowo University, Ile-Ife, Nigeria \\ ${ }^{2}$ Dept. of Forestry and Environmental Management, Micheal Okpara University of Agriculture, Umudike, Nigeria \\ Correspondence should be addressed to Aderonke Adetutu Okoya; ronkeokoya@yahoo.com
}

Received 22 November 2019; Revised 26 February 2020; Accepted 3 March 2020; Published 24 April 2020

Academic Editor: James Barker

Copyright (c) 2020 Aderonke Adetutu Okoya et al. This is an open access article distributed under the Creative Commons Attribution License, which permits unrestricted use, distribution, and reproduction in any medium, provided the original work is properly cited.

\begin{abstract}
Trihalomethanes (THMs) are formed when excess chlorine during chlorination of water reacts with organic material in water. They have mutagenic and carcinogenic properties. Moringa oleifera (MO) has found wide acceptance by many people in Nigeria who have used it for food for both humans and fauna, for health purposes, and as a coagulant for water treatment. However, the seed husks are currently discarded as waste and they have not been used as adsorbent to remove THMs from water. The physicochemical properties of both the treated and raw surface water were determined using standard methods, and the concentration of THMs was determined from the water treatment plant at different stages of treatment using gas chromatography with flame ionization detector (GC-FID). Recovery experiments were carried out to validate the procedure. The efficiencies of activated carbon of Moringa oleifera seed husk (MOSH) adsorbent for the removal of THMs in the water and as a coagulant for water treatment were also assessed. Batch adsorption experiments were carried out, and different parameters such as $\mathrm{pH}(5,7$, and 9), adsorbent dosage (0.2, 0.4, and $0.8 \mathrm{~g})$, contact time (30, 60 , and 90 minutes), and initial concentration $(0.2,0.4$, and $0.6 \mathrm{mg} / \mathrm{l})$ were optimized for the removal of trichloromethane and tribromomethane using the MOSH activated carbon. Experimental adsorption data from different initial concentrations of trichloromethane and tribromomethane were used to test conformity with Langmuir and Freundlich adsorption isotherms. The percentage recovery from our procedures ranged from $96.0 \pm 1.41$ to $100.0 \pm 0.00$ for trichloromethane while for tribromomethane the range was $60 \pm 2.82$ to $100.0 \pm 0.00$. The mean percentage adsorption efficiencies for the simulation experiment ranged from $34.365 \pm 1.41$ to $93.135 \pm 0.57$ and from $41.870 \pm 0.27$ to $94.655 \pm 0.41$ for trichloromethane and tribromomethane, respectively. The optimum conditions for both trichloromethane and tribromomethane were $\mathrm{pH} 9,0.8 \mathrm{~g}$ adsorbent dosage, 60-minute contact time, and $0.6 \mathrm{mg} / \mathrm{l}$ initial concentration. The optimum values of these parameters used for the adsorption of the two THMs in the surface water serving the treatment plant gave an efficiency of $100.00 \pm 0.00 \%$. The turbidity values for the coagulation experiment reduced from $9.76 \pm 0.03 \mathrm{NTU}$ in the raw water before coagulation to $5.92 \pm 0.13 \mathrm{NTU}$ after coagulation while all other physicochemical parameters of the surface water decreased in value except conductivity and total dissolved solid which increased from $104.5 \pm 3.54$ to $108.0 \pm 2.83 \mu \mathrm{S} / \mathrm{cm}$ and $63.00 \pm 11.31$ to $83.0 \pm 8.49 \mathrm{mg} / \mathrm{l}$, respectively. The experimental data best fit into Langmuir than Freundlich adsorption isotherm. The study concluded that MOSH activated carbon could serve as an adsorbent for the removal of THMs, calcium, and sulphur from water samples.
\end{abstract}

\section{Introduction}

Agricultural waste is a biomass by-product that results from the agricultural processes which may include stalks, leaves, seeds, shells, peels, husks, and straws [1, 2]. Agricultural waste also includes livestock and poultry waste. They are characterized by a wide range of sources and large quantities. Due to their quantity and lack of proper waste disposal system, the wastes always constitute pollution to the environment $[2,3]$. At present, researchers are already looking into ways to sustainably turn these wastes into valuable resources. Agricultural by-products are converted to useful 
and value-added products. Studies have shown that agricultural waste can be employed in the generation of products that can serve as alternatives to the commercially available ones. For example, products such as biochar and activated carbon/biochar have been reported to be produced from different agricultural wastes and they find application for different uses such as in water and wastewater treatment, thereby becoming another economic resource for agriculturists. M. oleifera species is cultivated across the globe because of its medicinal and nutritional value.

A study on local uses and geographical distribution of Moringa oleifera [4] that covers the major agroecological region in Nigeria clearly established that though considered a nonindigenous species, Moringa oleifera has found wide acceptance among various ethics in Nigeria, who have exploited its different uses (e.g., food, medicine, fodder, and as a coagulant for water treatment). All plant parts of Moringa oleifera are traditionally used for different purposes, but leaves are generally the most used $[4,5]$. As a result of this, it is obviously clear that a huge amount of the M. oleifera seed husk (MOSH) could be generated as solid waste, which needs to be managed. Previous research by Pollard et al. [6] found that carbonization of Moringa oleifera husks was carried out under $\mathrm{N}_{2}$ at $485^{\circ} \mathrm{C}$ for 30 minutes, followed by steam activation for 5 minutes at $850^{\circ} \mathrm{C}$, and produced a highly microporous carbon with adsorptive properties similar to commercial activated carbons. This is a complex production process involving two heating stages and the use of $\mathrm{N}_{2}$ gas. In a developing country like Nigeria, both chemical and energy costs are high, so any reduction in, or elimination of, the use of chemicals and any reduction of the energy required for the process will improve the economic case for carbon production. Hence, there is a need for a simple pyrolysis procedure to produce good quality activated carbon.

Also, water treatment is necessary in this age of burgeoning human population, and high demand for water resources and water reuse has surfaced in both urban and rural areas [7]. Portable water is becoming a scarce commodity, and the treatment of available water with disinfectant for domestic water supply sometimes leaves disinfectant by-products, such as THMs. THMs had been found to be the most widely spread organic contaminants in drinking water, and they are carcinogenic and sometimes mutagenic when ingested in high quantity.

Agricultural by-products are employed in water purification because the conventional methods available for the treatment of water and wastewater are expensive and not environment friendly and sometimes do leave by-products such as THMs that may be of concern. Adsorption has shown to be a more efficient and cost-effective method for removing many pollutants [2]. Different agricultural wastes have been used as adsorbent in the removal of pollutants. The agricultural wastes used include straw [8], wheat straw [9], bagasse [10], banana skin [11], walnut shell [12], and coconut shell $[13,14]$. Among the many promising low-cost materials that are possible to produce a biosorbent is the Moringa oleifera (MO), and its seeds have been used as coagulant and adsorbent for contaminants in water treatment. However, despite the increasing demand for MO plant for different purposes which leads to generation of waste such as the seed husk, there is a paucity of data on the use of Moringa oleifera seed husk (MOSH) for the removal of THMs from the aquatic environment. This study therefore seeks to determine the concentration of trihalomethanes present in the water supply, assess the adsorption efficiency of MOSH activated carbon for the removal of trihalomethanes, and evaluate the efficacy of MOSH as a coagulant for water treatment.

\section{Materials and Methodology}

2.1. Preparation and Carbonization of Sample. The Moringa oleifera seed husks (MOSH) were collected from a local farm in Nigeria. The MOSH were washed, sun-dried, and pulverized to increase the surface area for activated carbon production. Pulverized known weight $(100 \mathrm{~g})$ of the MOSH was prepared by placing the raw material in a crucible and incinerated in a furnace at $650^{\circ} \mathrm{C}$ for 30 minutes and sieved to $<150 \mu \mathrm{m}$ particle size $[15,16]$.

2.2. Chemical Activation of the Carbon. The method is as outlined in $[15,16]$. One hundred grams $(100 \mathrm{~g})$ of the pulverized $\mathrm{MOSH}$ was soaked in $2 \% \mathrm{H}_{3} \mathrm{PO}_{4}(\mathrm{v} / \mathrm{v})$ for 48 hours, filtered, and placed in an oven at a temperature of $110^{\circ} \mathrm{C}$ for $24 \mathrm{~h}$. After cooling, it was washed with freshly distilled water to remove the residual acids until the solution reaches a $\mathrm{pH}$ of 7 and used as an adsorbent.

\subsection{Characterization of the Activated Carbon. The elemental} composition and the surface morphological characteristics of the activated carbon were determined based on the dry combustion method using a scanning electron microscope coupled with energy dispersive X-ray analyzer (high-resolution SEM/ EDX, Carl Zeiss). Structural chemical functional groups in the activated carbon were determined using the Fourier transform infrared technique (FTIR, Spectrum 100, PerkinElmer).

\subsubsection{Preparation of Samples for SEM/EDX Analysis. The} Moringa oleifera seed husk (MOSH) activated carbon samples were placed on the aluminum holder stub using a double sticky carbon tape. Insulating samples were located with carbon and electrically grounded. Also, silver paint was used to electrically ground the samples. Then, the samples were completely dried in the drying oven at $60^{\circ} \mathrm{C}$ for about 3 hours and were left overnight in the drying oven. The samples were loaded in the SEM holder, and the SEM was switched on. The SEM instrument then placed the samples in a relative high-pressure chamber where the working distance is short, and the electron optical column is differentially pumped to keep vacuum adequately low at the electron gun. Imaging was then acquired.

The energy dispersive $\mathrm{X}$-ray acceleration voltage was then set to $20 \mathrm{kV}$ with a working distance of $14 \mathrm{~mm}$, and the detector was moved to $45 \mathrm{~mm}$ by rotating the knob, the samples were focused, and the X-ray spectrum was collected and saved in pgt file. 
2.3.2. Preparation of Samples for FTIR Analysis. The samples were analyzed using the FTIR KBr method. A drop of the liquid was placed on the face of a highly polished $\mathrm{KBr}$ plate. A second plate was placed on top of the first plate so as to spread the liquid in a thin layer between the plates and clamped together. Liquid on the edge of the plate was wiped after which the sample plate was mounted onto a sample holder connected to a recording device and analyzed.

\subsection{Batch Adsorption Experiment of Simulated Polluted} Water. The batch adsorption experiments were carried out according to the method described in $[17,18]$. THMs polluted water was simulated in the laboratory by preparing a separate stock solution of tribromomethane and trichloromethane and diluted to varying degrees of concentrations $(0.2,0.4$, and $0.6 \mathrm{mg} / \mathrm{l})$. Batch adsorption studies were carried out using $0.2,0.4$, and $0.8 \mathrm{~g}$ of the adsorbent made from $\mathrm{MOSH}$ and $50 \mathrm{ml}$ each of the simulated solution of THMs (tribromomethane and trichloromethane) polluted water in a different conical flask with constant shaking using a shaker operated at $120 \mathrm{osc} / \mathrm{min}$. The parameters such as $\mathrm{pH}$, adsorbent dosage, contact time, and initial THMs (tribromomethane and trichloromethane) concentration were optimized for successful adsorption. The batch adsorptions were followed by filtration using Whatman filter paper (No. 1). The filtrates containing the residual concentration of the trihalomethanes under study were determined using gas chromatography (GC-FID). The data obtained were subjected to paired-sample $T$-test and oneway analysis of variance.

2.5. Gas Chromatography Analysis. Agilent 7890 series gas chromatography coupled with a flame ionization detector (GC-FID) was used for determining trichloromethane and tribromomethane, and identification was based on the retention time. The equipment was installed with ChemStation software for operation, data analyses, and reporting. The column has a HP-5 fused silica capillary column with a maximum length of $30 \mathrm{~m}$, a diameter of $250 \mu \mathrm{m}$, and a film thickness of $0.25 \mu \mathrm{m}$. The GC-FID uses helium gas as its carrier gas. The column temperature was programmed from $40^{\circ} \mathrm{C}$ for $2 \mathrm{~min}$ and increased at the rate of $6^{\circ} \mathrm{C} / \mathrm{min}$ to $120^{\circ} \mathrm{C}$, held for $2 \mathrm{~min}$, and then continued at a rate of $20^{\circ} \mathrm{C} / \mathrm{min}$ to $250^{\circ} \mathrm{C}$ and held for $5 \mathrm{~min}$ [19] so as to enhance good resolution at different boiling points. The oven temperature was $300^{\circ} \mathrm{C}$ with an equilibrium time of 0.25 minutes, at a pressure of $11.604 \mathrm{psi}$, and a peak flow rate of $104.5 \mathrm{ml} / \mathrm{min}$. The injection was done on a splitless mode injector at $250^{\circ} \mathrm{C}$, and the run time was 45.75 minutes.

2.6. Coagulation Test. The analysis of optimum dosage required for Moringa oleifera seed husk (MOSH) activated carbon was conducted following the jar test apparatus which is the method commonly used for simulating the coagulation-flocculation process $[20,21]$. Two conical flasks of $250 \mathrm{ml}$ volume each were employed and filled with $200 \mathrm{ml}$ of the water sample. The adsorbent dosage with the highest adsorption efficiency $(0.8 \mathrm{~g})$ during the simulation experiment was used. The solutions were mixed rapidly for $2 \mathrm{~min}$, followed by $10 \mathrm{~min}$ of gentle mixing using a glass rod to aid the coagulation. The suspensions were left to stand without disturbance for $60 \mathrm{~min}$. The supernatants formed were decanted and subjected to turbidity, $\mathrm{pH}$, conductivity, and total dissolved solid measurements. The turbidity was analyzed with a direct reading turbidimeter $(\mathrm{HACH} 2100 \mathrm{P})$ with a precision of 0.01 , while the $\mathrm{pH}$, conductivity, and total dissolved solids were measured using $\mathrm{pH} / \mathrm{EC} / \mathrm{TDS}$ Temperature Meter.

\subsection{Recovery Experiment for the Extraction Process and De-} termination of Trichloromethane and Tribromomethane. Liquid/liquid extraction method (LLE) described by [22, 23] was adopted for the extraction of water samples. Acidified raw water $(100 \mathrm{ml})$ spiked with $50 \mathrm{ml}$ of $0.4 \mathrm{mg} / \mathrm{L}$ of trichloromethane and tribromomethane concentration of the standard mixture was extracted with $15 \mathrm{ml}$ of dichloromethane (DCM). Two grams of anhydrous sodium sulphate (Merck, Germany) was added to the collected extracts to remove the residual water. The collected extract was then concentrated to about $2 \mathrm{ml}$ at room temperature for chromatographic clean-up according to the method of Okoya et al. [23]. Recoveries of trichloromethane and tribromomethane standards were also investigated by spiking deionized water sample to check on the effect of matrix on extraction efficiencies. The equation of recovery experiment residual concentration is shown as follows [24]:

$\%$ recovery $=\frac{\text { spiked concentration }- \text { unspiked concentration }}{\text { spiked concentration }}$.

\section{Results and Discussion}

3.1. Physicochemical Parameters of Water Samples before and after Adsorption. The physicochemical parameters of raw surface and treated water samples before adsorption were carried out to determine the range of values of contaminants before and after the adsorption experiment. All the parameters fall within the WHO limits after the adsorption experiment (Table 1). This is in agreement with the work of Adewole et al. [25] who worked on the efficacy of natural coagulant protein from Moringa oleifera (Lam) seeds in the treatment of water. The study concludes that Moringa oleifera coagulant protein showed biocoagulation activity which is an exploitatable property, since the quality parameters of water treated with the protein met most of the Nigerian standard for drinking water quality. The results are presented in Table 1 and showed that parameters such as temperature, conductivity, turbidity, $\mathrm{Cl}^{-}, \mathrm{NO}_{3}{ }^{-}, \mathrm{DO}, \mathrm{TOC}$, $\mathrm{BOD}$, and alkalinity decreased in concentration after adsorption for both the raw and treated water while $\mathrm{pH}$, total suspended solids, and acidity decreased for raw water sample and increased for treated water.

The trend observed for the conductivity, $\mathrm{Cl}^{-}$, and the $\mathrm{NO}_{3-}$ ions is expected since conductivity usually correlates with major ions and total dissolved solids. It is also an 
TABLE 1: Physicochemical analysis of influent raw and treated water before and after adsorption.

\begin{tabular}{|c|c|c|c|c|c|c|c|}
\hline $\mathrm{S} / \mathrm{N}$ & Parameters & Units & $\begin{array}{l}\text { Raw water } \\
\text { before } \\
\text { adsorption }\end{array}$ & $\begin{array}{l}\text { Treated water } \\
\text { before } \\
\text { adsorption }\end{array}$ & $\begin{array}{l}\text { Raw water } \\
\text { after } \\
\text { adsorption }\end{array}$ & $\begin{array}{l}\text { Treated water } \\
\text { after adsorption }\end{array}$ & $\begin{array}{l}\text { WHO } \\
\text { standards } \\
\text { guideline } \\
\text { values }\end{array}$ \\
\hline 1 & Temperature & ${ }^{\circ} \mathrm{C}$ & $27.6 \pm 0.14$ & $27.15 \pm 0.07$ & $23.6 \pm 1.55$ & $26.11 \pm 1.12$ & $25-32$ \\
\hline 2 & Conductivity & $\mu \mathrm{s} / \mathrm{cm}$ & $104.5 \pm 3.54$ & $108.5 \pm 0.71$ & $89.5 \pm 3.53$ & $102 \pm 1.41$ & 2500 \\
\hline 3 & $\mathrm{pH}$ & - & $6.8 \pm 0.00$ & $5.64 \pm 0.12$ & $6.5 \pm 0.14$ & $6.6 \pm 0.11$ & 6.5 \\
\hline 4 & TDS & $\mathrm{mg} / \mathrm{l}$ & $63.00 \pm 11.31$ & $64.5 \pm 0.71$ & $68.00 \pm 1.41$ & $60.5 \pm 2.12$ & 500 \\
\hline 5 & $\mathrm{NO}_{2}^{-}$ & $\mathrm{mg} / \mathrm{l}$ & ND & ND & ND & ND & 0 \\
\hline 6 & $\mathrm{NO}_{3}^{-}$ & $\mathrm{mg} / \mathrm{l}$ & $0.78 \pm 0.00$ & $0.27 \pm 0.00$ & $0.58 \pm 0.00$ & $0.24 \pm 0.00$ & 10 \\
\hline 7 & TSS & $\mathrm{mg} / \mathrm{l}$ & $2.87 \pm 0.00$ & $1.67 \pm 0.00$ & $1.9 \pm 0.03$ & $1.81 \pm 0.20$ & 100 \\
\hline 8 & Turbidity & NTU & $9.76 \pm 0.03$ & $1.84 \pm 0.24$ & $5.03 \pm 0.39$ & $1.03 \pm 0.08$ & 5 \\
\hline 9 & $\mathrm{SO}_{4}{ }^{2-}$ & $\mathrm{mg} / \mathrm{l}$ & $5.48 \pm 0.01$ & $0.31 \pm 0.01$ & $4.49 \pm 0.86$ & $3.76 \pm 0.34$ & 400 \\
\hline 10 & $\mathrm{Cl}^{-}$ & $\mathrm{mg} / \mathrm{l}$ & $25.85 \pm 1.91$ & $7.26 \pm 0.41$ & $12.69 \pm 1.61$ & $3.29 \pm 1.37$ & $250-1000$ \\
\hline 11 & TOC & $\mathrm{mg} / \mathrm{l}$ & $5.78 \pm 0.00$ & $4.33 \pm 0.08$ & $0.64 \pm 0.02$ & $0.41 \pm 0.05$ & 25 \\
\hline 12 & BOD & $\mathrm{mg} / \mathrm{l}$ & $34.07 \pm 0.00$ & $4.79 \pm 0.31$ & $14.01 \pm 3.43$ & $2.19 \pm 0.00$ & 30 \\
\hline 13 & COD & $\mathrm{mg} / \mathrm{l}$ & $20.28 \pm 0.00$ & $3.24 \pm 0.00$ & $19.58 \pm 0.00$ & $3.54 \pm 1.11$ & 250 \\
\hline 14 & DO & $\mathrm{mg} / \mathrm{l}$ & $9.03 \pm 0.01$ & $2.31 \pm 0.01$ & ND & ND & $4-7$ \\
\hline 15 & Acidity & $\mathrm{mgCaCO}_{3}{ }^{\mathrm{L}-1}$ & $5.85 \pm 0.07$ & $0.23 \pm 0.08$ & $5.03 \pm 0.19$ & $1.67 \pm 0.01$ & 5.5 \\
\hline 16 & Alkalinity & $\mathrm{mg} / \mathrm{l}$ & $71.88 \pm 0.30$ & $52.02 \pm 7.07$ & $54.12 \pm 2.22$ & $44.1 \pm 1.27$ & 50 \\
\hline 17 & $\begin{array}{l}\text { Trichloromethane ( } M \text {. oleifera seed } \\
\text { husk activated carbon using GC- } \\
\text { FID) }\end{array}$ & $\mathrm{mg} / \mathrm{l}$ & $0.5395 \pm 0.033$ & $0.255 \pm 0.086$ & $\begin{array}{c}\text { Below } \\
\text { detection limit }\end{array}$ & $\begin{array}{c}\text { Below detection } \\
\text { limit }\end{array}$ & 0.3 \\
\hline 18 & $\begin{array}{l}\text { Tribromomethane (M. oleifera seed } \\
\text { husk activated carbon using GC- } \\
\text { FID) }\end{array}$ & $\mathrm{mg} / \mathrm{l}$ & $0.5725 \pm 0.038$ & $0.288 \pm 0.089$ & $\begin{array}{c}\text { Below } \\
\text { detection limit }\end{array}$ & $\begin{array}{c}\text { Below detection } \\
\text { limit }\end{array}$ & 0.1 \\
\hline
\end{tabular}

indication that the $\mathrm{Cl}^{-}$and $\mathrm{NO}_{3-}$ are in solution. It is in order to observe TOC and BOD following the same trend according to scientific standards that both TOC and BOD are directly proportional to each other, and a decrease in BOD implies that adsorption process has an impact on the organic matter by implication, and hence the THMs which are formed by the reaction of organic matter and chlorine in water.

3.2. Characterization of Activated Carbon. The results of the physicochemical parameters (carbon yield, the ash content, $\mathrm{pH}$, and moisture content) of MOSH activated carbon are presented in Table 2. The high percentage carbon yield from MOSH obtained makes it an asset compared to other agricultural wastes and fossil fuel sources [26] with low carbon yield because it can serve as one of the income sources of agro-based industries. High carbon yield and low ash content give better characteristics of pore structures and this led to the established fact that high carbon yield of agricultural waste is indicative of good adsorption. Also from Table 2, the $\mathrm{pH}$ of 5.8 is indicative of an acidic substrate. Activated carbon is usually amphoteric in nature and it implies it could be positively or negatively charged depending on the solution $\mathrm{pH}$; in this case, the solution $\mathrm{pH}$ will be positively charged. Attraction between activated carbon and anionic or cationic adsorbate is mainly related to the surface characteristics. More positively charged surfaces are obtained at lower $\mathrm{pH}$ values and this favours the uptake of more anionic groups due to increased electrostatic attraction between anions and the surface of the activated carbon [27].
TABle 2: Physicochemical parameters of Moringa oleifera seed husk activated carbon.

\begin{tabular}{lcc}
\hline Parameter & Unit & $\begin{array}{c}\text { Moringa oleifera seed husk activated } \\
\text { carbon }\end{array}$ \\
\hline $\mathrm{pH}$ & - & $5.8 \pm 0.36$ \\
Carbon yield & $(\%)$ & $81.8 \pm 0.43$ \\
Ash content & $(\%)$ & $4.2 \pm 0.55$ \\
Moisture content & $(\%)$ & $7.1 \pm 0.32$ \\
\hline
\end{tabular}

3.3. Elemental Composition of the Activated Carbon before and after Adsorption. The MOSH activated carbon was analyzed using scanning electron microscope coupled with energy dispersive X-ray analyzer (SEM/EDX) (high-resolution SEM/ EDX, Carl Zeiss) to determine its elemental composition before and after adsorption experiment (Table 3). The result shows that carbon has the highest percentage (45.5\%) before adsorption while it was 91.51 and $95.51 \%$, respectively, after adsorption for raw and treated water samples of all the elements present, and this makes the Moringa oleifera seed husk (MOSH) activated carbon suitable for adsorption [15, 28, 29]. The decrease in the percentage of oxygen after adsorption could be attributed to utilization of oxygen to oxidize MOSH which is of organic origin. Also the occurrence of sulphur and calcium after adsorption in the activated carbon could imply that the activated carbon is also effective for the removal of sulphur and calcium from the water samples (Table 3 ).

3.4. Surface Morphology of Moringa oleifera Seed Husk Activated Carbon before and after Adsorption Experiment. The surface morphological characteristic of the adsorbent is shown by the scanning electron micrograph. Figure 1(a) 
TABLE 3: Percentage composition of the elements in Moringa oleifera seed husk (MOSH) activated carbon.

\begin{tabular}{lccc}
\hline \multirow{2}{*}{ Elements (\%) } & Before adsorption amount (\%) & $\begin{array}{c}\text { After adsorption amount (\%) } \\
\text { Raw }\end{array}$ & $\begin{array}{c}\text { After adsorption amount (\%) } \\
\text { Treated }\end{array}$ \\
\hline Carbon & 45.5 & 91.51 & 95.51 \\
Chromium & 3.0 & - & - \\
Oxygen & 10.0 & 3.50 & 3.53 \\
Silicon & 20.5 & 4.20 & - \\
Zinc & 31.0 & - & - \\
Calcium & - & 0.45 & 0.42 \\
Sulphur & - & 0.34 & 0.54 \\
\hline
\end{tabular}

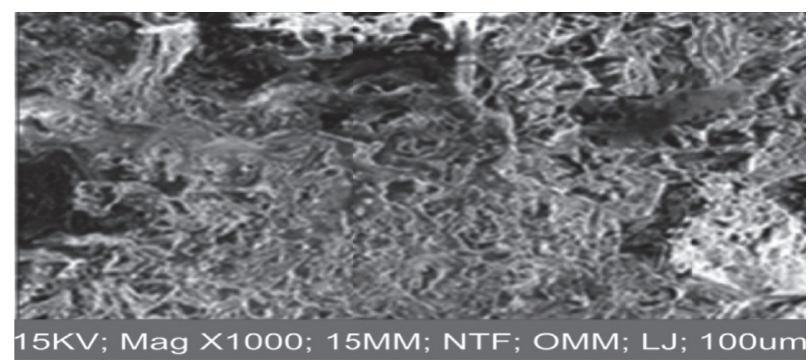

(a)
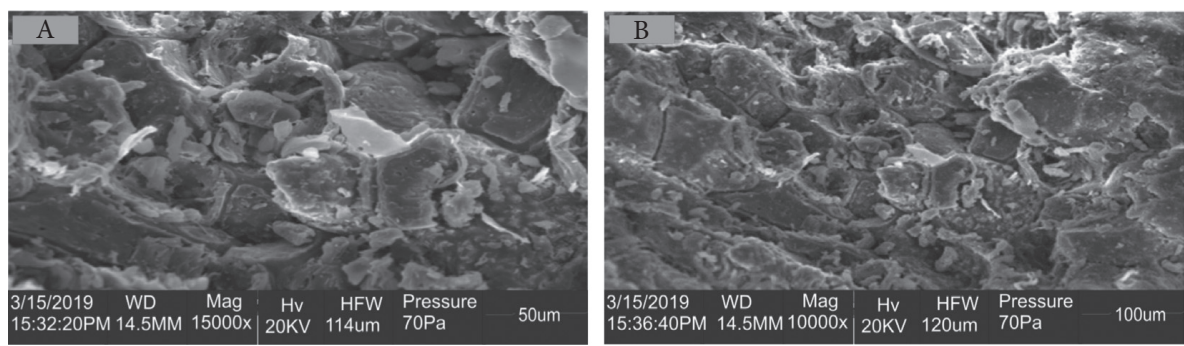

(b)

FIGURE 1: (a) Scanning electron micrograph of Moringa oleifera seed husk activated carbon before adsorption. (b) Scanning electron micrograph of Moringa oleifera seed husk activated carbon after adsorption of trichloromethane and tribromomethane from (A) treated water and (B) raw water samples.

shows the surface morphology of the activated carbon (adsorbent) before and Figure 1(b) A and B after adsorption process. This explains the mass of particle and the surface morphology of the adsorbent. The surface of the adsorbent before adsorption shows wavy-like curves with perfect pore sizes which enable access into the internal pores. However, after adsorption, it was observed that the pores were already clogged with the trichloromethane and tribromomethane contaminants adsorbed on the activated carbon indicating adsorption had taken place.

3.5. Functional Groups of Moringa oleifera Seed Husk Activated Carbon. The functional groups of the Moringa oleifera seed husk activated carbon were determined using Fourier transform-infrared spectroscopy (SHIMADZU-FTIR8400 S). Figure 2 shows the functional groups present in the activated carbon of Moringa oleifera seed husk. Each of the bands on the FTIR represents a particular functional group which enables adsorption. The functional groups present are the hydroxyl $\left(3209.66^{-1}\right.$ and $\left.3059.20 \mathrm{~cm}^{-1}\right)$, carbonyl $\left(879.57 \mathrm{~cm}^{-1}\right)$, aldehydes $\left(759.98 \mathrm{~cm}^{-1}\right)$, ester $\left(669.32 \mathrm{~cm}^{-1}\right)$, carbonate ester $\left(1572.04 \mathrm{~cm}^{-1}\right)$, carboxyl $\left(3209.66 \mathrm{~cm}^{-1}\right)$, ether $\left(1139.97 \mathrm{~cm}^{-1}\right)$, and methoxy groups $\left(2212.43 \mathrm{~cm}^{-1}\right)$.

3.6. Batch Adsorption Studies on Simulated Solution of Trichloromethane and Tribromomethane Using MOSH Activated Carbon as Adsorbent. The efficiency of MOSH activated carbon as adsorbent for the adsorption of trichloromethane and tribromomethane was investigated. The parameters such as $\mathrm{pH}$, adsorbent dosage, contact time, and concentrations affecting the adsorption were studied using the MOSH activated carbon. The results of the effects of each of the parameters are presented as follows.

3.6.1. Effect of $p H$ on Adsorption of Trichloromethane and Tribromomethane in Simulated Experiment. The results of the investigation on the adsorption of trichloromethane and tribromomethane on Moringa oleifera seed husk activated carbon with varied $\mathrm{pH}(5,7$, and 9) are presented in Figure 3 while all other conditions (adsorbent dosage, contact time, 


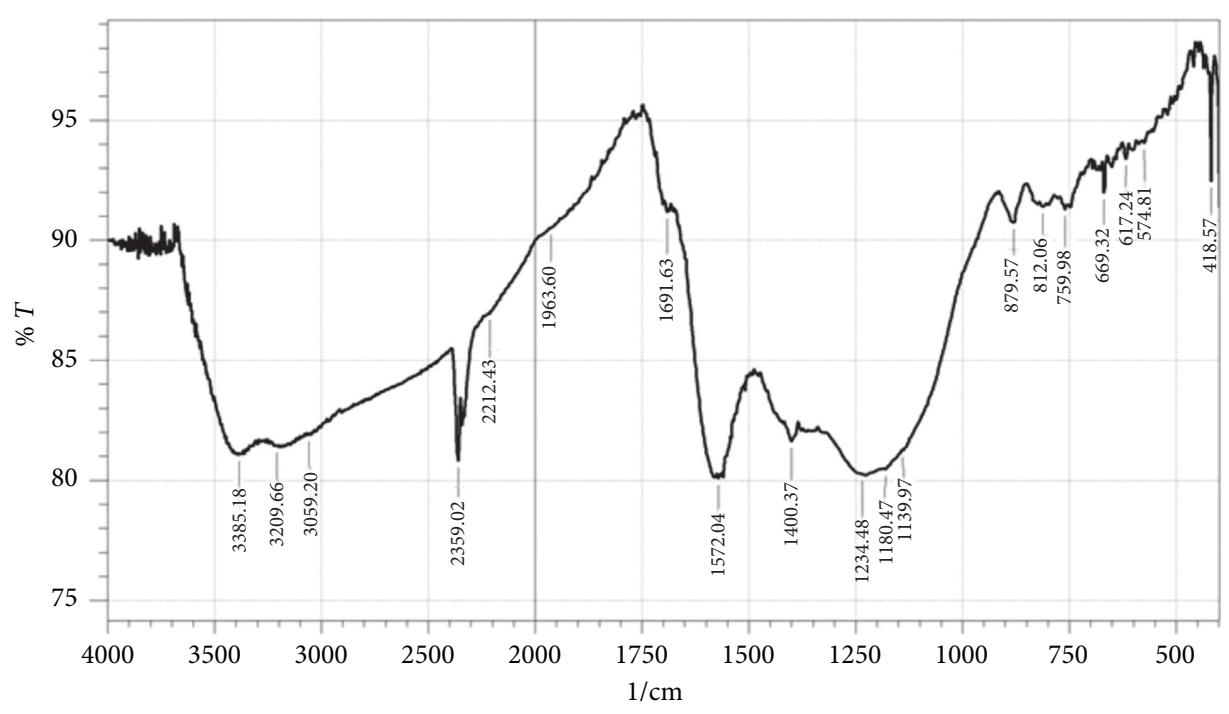

FIGURE 2: FTIR spectrum of Moringa oleifera seed husk activated carbon.

and concentration) were kept constant. The removal efficiency of trichloromethane was $90.5 \%$ at $\mathrm{pH}$ of $5,58.65 \%$ at $\mathrm{pH}$ of 7 , and $92.7 \%$ at $\mathrm{pH}$ of 9 , while the removal efficiency of tribromomethane was $92.06 \%$ at $\mathrm{pH}$ of $5,55.8 \%$ at $\mathrm{pH}$ of 7 , and $94.95 \%$ at $\mathrm{pH}$ of 9 . This trend may be due to the presence of hydroxyl bonds on the adsorbent as revealed in the FTIR results and it is in line with the report of $[16,30]$. This also shows that adsorption of THMs using MOSH activated can be optimal at both acidic and basic medium.

3.6.2. Effect of Adsorbent Dosage on Adsorption of Trichloromethane and Tribromomethane in Simulated Experiment. The result of different adsorbent dosages for the adsorption of trichloromethane and tribromomethane by Moringa oleifera seed husk activated carbon is presented in Figure 4 while all other conditions $(\mathrm{pH}$, initial concentration, and contact time) were kept constant. The removal efficiency of trichloromethane was $53.64 \%$ at adsorbent dosage of $0.2 \mathrm{~g}$, $71.35 \%$ at adsorbent dosage of $0.4 \mathrm{~g}$, and $73.68 \%$ at adsorbent dosage of $0.8 \mathrm{~g}$, while the removal efficiency of tribromomethane was $44.1 \%$ at adsorbent dosage of $0.2 \mathrm{~g}, 71.93 \%$ at adsorbent dosage of $0.4 \mathrm{~g}$, and $76.80 \%$ at adsorbent dosage of $0.8 \mathrm{~g}$. This shows that the efficiency of adsorption increases with increase in adsorbent dosage. This is because as adsorbent dose increases, free sorption surface and adsorption sites also increase, thereby adsorbing more trichloromethane and tribromomethane [31-33]. Adsorbent dose of $0.8 \mathrm{~g}$ gave the highest removal efficiency for this study. However, from economic point of view, adsorbent dosage of $0.2 \mathrm{~g}$ will be considered as the best dosage of $\mathrm{MOSH}$ activated carbon for this study.

3.6.3. Effect of Contact Time on Adsorption of Trichloromethane and Tribromomethane in Simulated Experiment. The results of the adsorption of trichloromethane and tribromomethane on MOSH activated carbon by varying contact time (30, 60, and 90 minutes) are presented in Figure 5 while other conditions ( $\mathrm{pH}$, adsorbent dosage, and concentration)

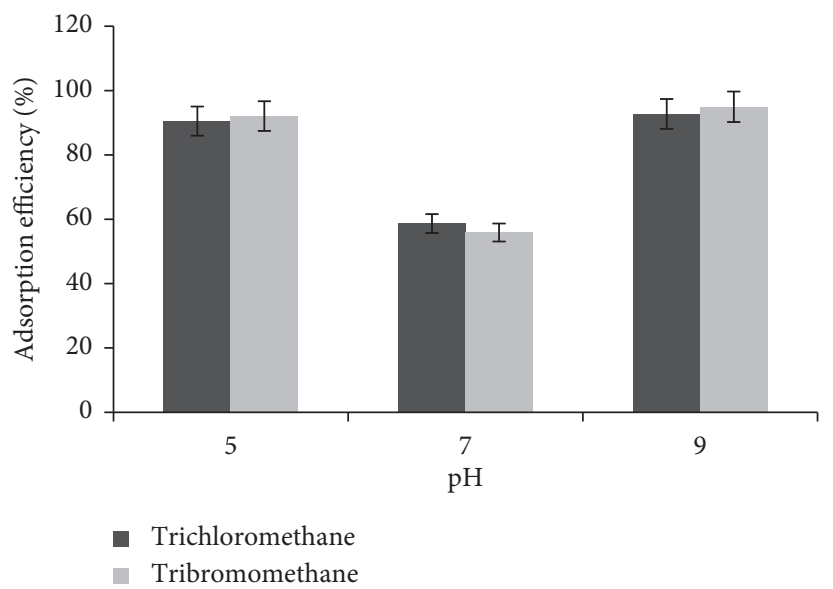

Figure 3: Effect of $\mathrm{pH}$ on adsorption of trichloromethane and tribromomethane in simulated experiment.

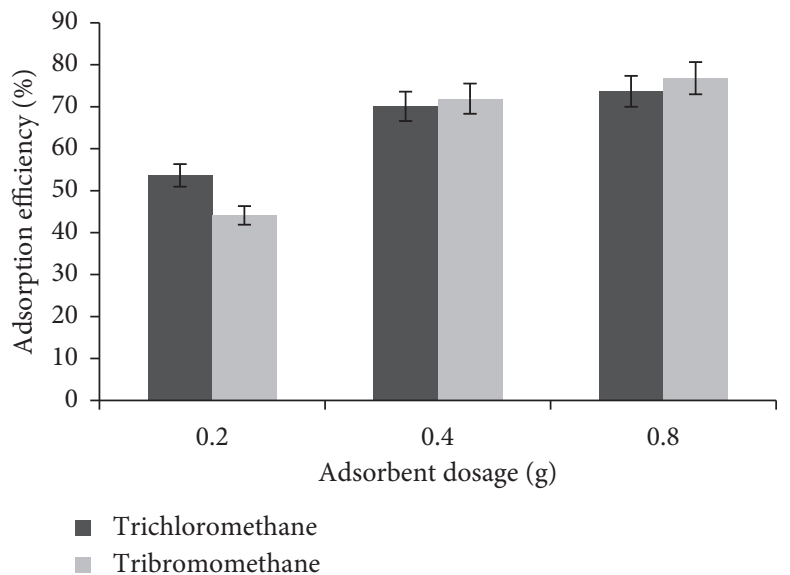

FIGURE 4: Effect of adsorbent dosage on adsorption of trichloromethane and tribromomethane in simulated experiment. 


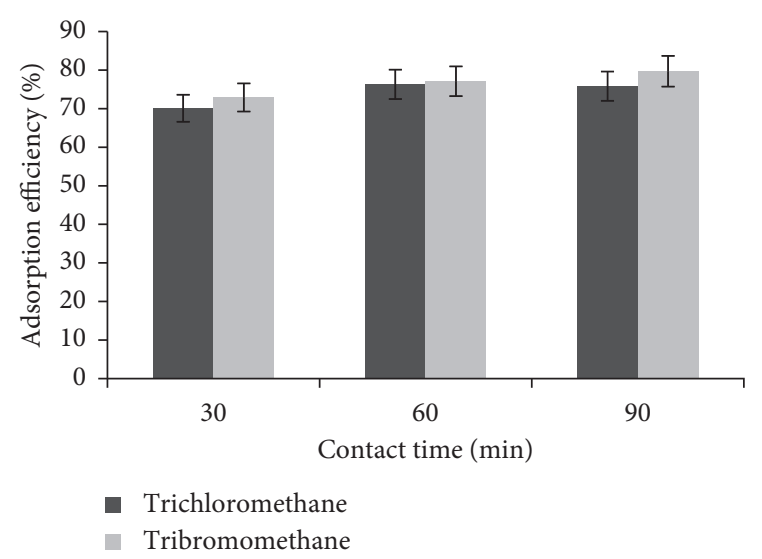

FIGURE 5: Effect of contact time on adsorption of trichloromethane and tribromomethane in simulated experiment.

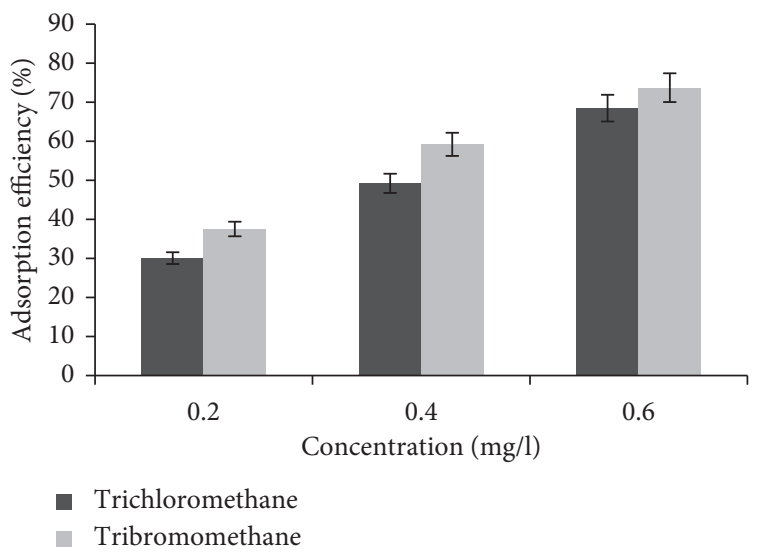

FIGURE 6: Effect of initial concentration on adsorption of trichloromethane and tribromomethane in simulated experiment.

were kept constant. The removal efficiency of trichloromethane was $70.17 \%, 76.27 \%$, and $75.83 \%$ at contact time of 30,60 , and 90 minutes, respectively, while the removal efficiency of tribromomethane was $72.9 \%, 79.2 \%$, and $79.67 \%$ at contact time of 30,60 , and 90 minutes, respectively. However, the equilibrium was set up at 60 minutes for the two THMs studied. This might be due to the initial availability of vacant sites for adsorption. The dynamic increment in adsorption and consequently the attainment of equilibrium adsorption may be due to limited mass transfer of THMs molecules from the bulk solution to the surface of the adsorbent [32]. A similar phenomenon was observed on the application of modified synthetic carbon for adsorption of THMs from water [17] and adsorption methyl parathion pesticides from water using water melon peel as low-cost adsorbent according to Memon et al. [34].

3.6.4. Effect of Initial Concentration on Adsorption of Trichloromethane and Tribromomethane in Simulated Experiment. The results obtained from the investigation of the adsorption of trichloromethane and tribromomethane using MOSH activated carbon with varied initial concentration $(0.2,0.4$,
TABle 4: Adsorption efficiency of Moringa oleifera seed husk activated carbon on raw and treated water.

\begin{tabular}{lccc}
\hline Contaminant & Adsorbent & $\begin{array}{c}\text { Adsorption efficiency } \\
\text { (\%) }\end{array}$ \\
\hline Trichloromethane & $\begin{array}{c}\text { Moringa oleifera seed } \\
\text { husk }\end{array}$ & $\begin{array}{c}\text { Treated } \\
\text { water }\end{array}$ \\
\hline Tribromomethane & Activated carbon & $100 \pm 0.00$ & $100 \pm 0.00$ \\
\hline Confidence level $=0.05 ;$ significant value $=1.000 .00$ & $100 \pm 0.00$ \\
\hline
\end{tabular}

and $0.6 \mathrm{mg} / \mathrm{l})$ are presented in Figure 6 . The removal efficiency of trichloromethane increased from 33.37 to 54.74 and $76.14 \%$ at 0.2 to 0.4 and $0.6 \mathrm{mg} / \mathrm{l}$, respectively, while the removal efficiency of tribromomethane increased from $41.68 \%$ at initial concentration of $0.2 \mathrm{mg} / 1,71.07 \%$ at $0.4 \mathrm{mg} /$ $\mathrm{l}$, and to $81.98 \%$ at $0.6 \mathrm{mg} / \mathrm{l}$. The two THMs removal efficiencies were observed to increase with increase in initial concentration. The highest adsorption efficiency was recorded for the two THMs concentration of $0.6 \mathrm{mg} / \mathrm{l}$ while the lowest was observed at $0.2 \mathrm{mg} / \mathrm{l}$. This is in agreement with Lu et al. [32].

3.7. Adsorption Study on Influent Raw Water and Treated Water. Adsorption studies were conducted on raw surface and the treated water from the water treatment plant using MOSH activated carbon as adsorbent with the optimized conditions $(\mathrm{pH}$ 9, adsorbent dosage 0.8, and 60-minute contact time) from simulated experiments. The two THMs concentrations of raw and treated water samples were determined using gas chromatography with flame ionization detector (GC-FID) and the concentrations were $0.5395 \pm 0.033$ and $0.5725 \pm 0.038 \mathrm{mg} / \mathrm{l}$ for two THMs in raw water samples and $0.255 \pm 0.086$ and $0.288 \pm 0.089$ for the two THMs in treated water. The result showed that the removal efficiency of MOSH activated carbon for adsorption of trichloromethane and tribromomethane was below detection limit $(0.00 \mathrm{mg} / \mathrm{l})$ in both treated and raw water samples (as presented in Table 4) which implies $100 \%$ adsorption efficiency. This could be attributed to the fact that activated carbon produced from MOSH showed excellent performance in water treatment due to the high percentage adsorption efficiency. Also Nguyen et al. and Morawski and Inagaki $[16,17]$ reported that natural activated carbon removed a greater percentage of THMs in domestic water as well as wastewater.

3.8. Evaluation of the Efficiency of Moringa oleifera Seed Husk Activated Carbon as a Coagulant for Water Treatment. The results of the evaluation of the efficacy of MOSH activated carbon coagulation test are presented in Table 5. The results of the physicochemical investigation performed on the raw and treated water before and after coagulation test are presented in Table 5. It was observed that turbidity of the raw and treated water sample decreases after treatment. The turbidity value decreases from $5.92 \pm 0.13$ to $4.92 \pm 0.52 \mathrm{NTU}$ for treated water sample while the value for the raw water 
TABLE 5: Physicochemical analysis of influent raw and treated water before and after the evaluation of the efficiency of $M$. oleifera seed husk activated carbon coagulation test.

\begin{tabular}{lccccccc}
\hline $\mathrm{S} /$ & Parameters & Units & $\begin{array}{c}\text { Raw water before } \\
\text { coagulation test }\end{array}$ & $\begin{array}{c}\text { Treated water before } \\
\text { coagulation test }\end{array}$ & $\begin{array}{c}\text { Raw water after } \\
\text { coagulation test }\end{array}$ & $\begin{array}{c}\text { Treated water after } \\
\text { coagulation test }\end{array}$ & $\begin{array}{c}\text { WHO standards } \\
\text { guideline values }\end{array}$ \\
\hline 1 & $\mathrm{pH}$ & - & $6.8 \pm 0.00$ & $5.64 \pm 0.12$ & $5.64 \pm 0.06$ & $6.04 \pm 0.01$ & 6.5 \\
2 & Conductivity & $\mu \mathrm{s} / \mathrm{cm}$ & $104.5 \pm 3.54$ & $108.5 \pm 0.71$ & $108 \pm 2.83$ & $110 \pm 7.07$ & 2500 \\
3 & Turbidity & $\mathrm{NTU}$ & $9.76 \pm 0.03$ & $1.84 \pm 0.24$ & $5.92 \pm 0.13$ & $4.92 \pm 0.52$ & 5 \\
4 & $\begin{array}{c}\text { Total dissolved } \\
\text { solids }\end{array}$ & $\mathrm{mg} / \mathrm{l}$ & $63.00 \pm 11.31$ & $64.5 \pm 0.71$ & $83 \pm 8.49$ & $94 \pm 12.73$ & 500 \\
\hline
\end{tabular}

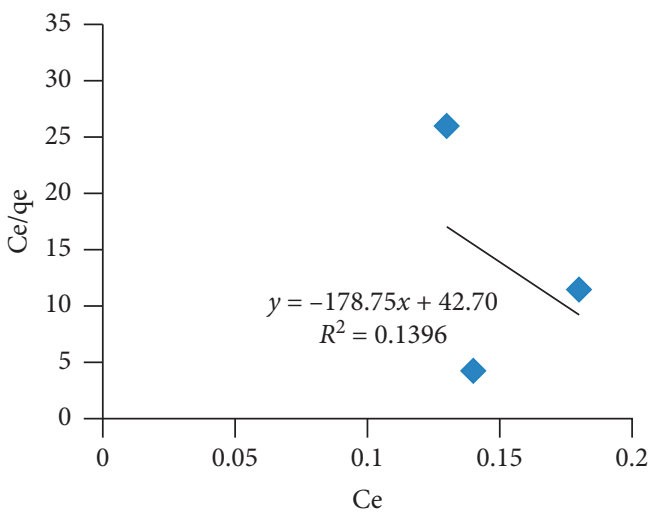

Trichloromethane

Linear (trichloromethane)

(a)

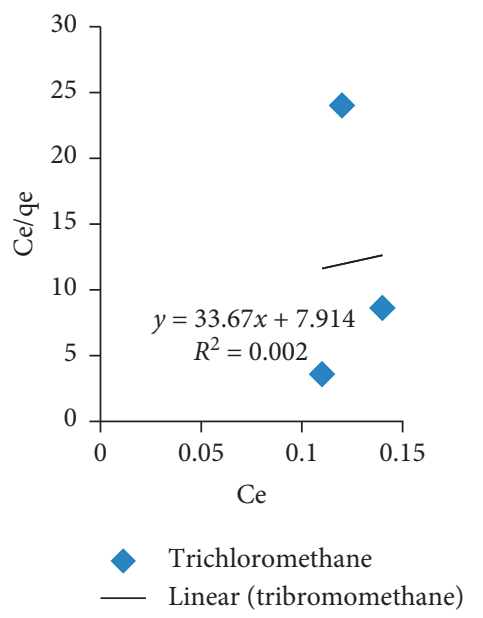

(b)

FIGURE 7: Langmuir adsorption isotherms for the adsorption of (a) trichloromethane and (b) tribromomethane using Moringa oleifera seed husk activated carbon.

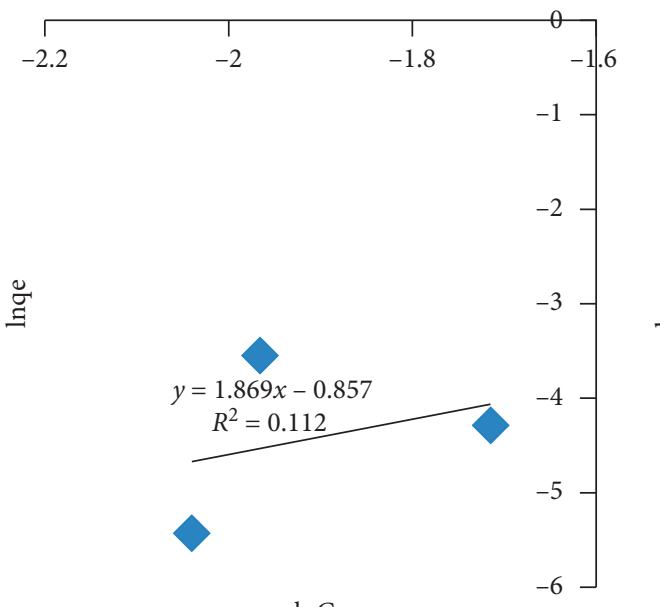

$\ln \mathrm{Ce}$

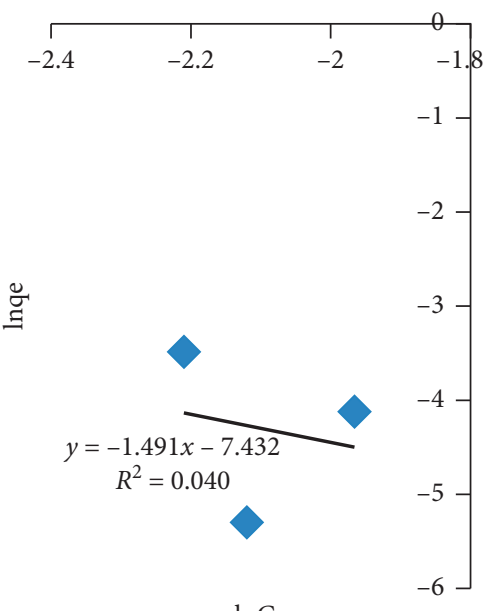

$\operatorname{lnCe}$
Trichloromethane

Linear (trichloromethane)

(a)
Trichloromethane

Linear (tribromomethane)

(b)

FIGURE 8: Freundlich adsorption isotherms for the adsorption of (a) trichloromethane and (b) tribromomethane using Moringa oleifera seed husk activated carbon. 
TABLE 6: Mean percentage (\%) recoveries of trichloromethane and tribromomethane from raw, treated and blank water samples after extraction with Dichloromethane.

\begin{tabular}{|c|c|c|c|}
\hline Sample ID & Unspiked concentration $(\mathrm{mg} / \mathrm{l})$ & Spiked concentration $(\mathrm{mg} / \mathrm{l})$ & $\%$ recovery \\
\hline \multicolumn{4}{|l|}{ Raw water sample } \\
\hline Trichloromethane & 0.5624 & 10.000 & $96 \pm 1.41$ \\
\hline Tribromomethane & 0.5994 & 10.000 & $95 \pm 1.21$ \\
\hline \multicolumn{4}{|l|}{ Treated water sample } \\
\hline Trichloromethane & 0.3161 & 9.938 & $96 \pm 0.70$ \\
\hline Tribromomethane & 0.3514 & 6.172 & $60 \pm 2.82$ \\
\hline \multicolumn{4}{|l|}{ Blank water sample } \\
\hline Trichloromethane & 0.000 & 15.734 & $100 \pm 0.00$ \\
\hline Tribromomethane & 0.000 & 10.932 & $100 \pm 0.00$ \\
\hline
\end{tabular}

TABLE 7: Langmuir and Freundlich constants for the adsorption of trichloromethane and tribromomethane using Moringa oleifera seed husk activated carbon.

\begin{tabular}{|c|c|c|c|c|c|c|c|}
\hline \multirow{2}{*}{$\begin{array}{l}\text { Adsorbent } \\
\text { Moringa oleifera seed husk activated carbon }\end{array}$} & \multirow[t]{2}{*}{ Contaminants } & \multicolumn{4}{|c|}{ Langmuir constants } & \multicolumn{2}{|c|}{ Freundlich constants } \\
\hline & & $q_{\mathrm{m}}(\mathrm{mg} / \mathrm{g})$ & $k_{\mathrm{a}}(\mathrm{L} / \mathrm{mg})$ & $R^{2}$ & $I / n$ & $k_{\mathrm{f}}\left(\mathrm{mg} / \mathrm{g}(\mathrm{l} / \mathrm{mg})^{1 / n}\right)$ & $R^{2}$ \\
\hline & & -5 & & 0.139 & 1.869 & 0.424 & 0.112 \\
\hline & Tribromomethane & 0.0297 & 4.255 & 0.002 & -1.491 & 5.920 & 0.040 \\
\hline
\end{tabular}

$R^{2}=$ correlation coefficient.

sample reduces from $9.76 \pm 0.03$ to $1.84 \pm 0.24$ NTU. $\mathrm{pH}$ value was also observed to decrease for raw water sample but increased in the treated water sample. Conductivity and TDS values were observed to increase for both the raw and treated water. Despite these trends observed in the result, the physicochemical parameter values were observed to be lower than the WHO standards. The result affirms the use of Moringa oleifera seed husk activated carbon as a coagulant to treat low turbid water.

3.9. Recovery Experiment for the Extraction Process and Determination of Trichloromethane and Tribromomethane. The results for the recovery experiment for the extraction process and determination of trichloromethane and tribromomethane are presented in Table 6. The percentage recoveries for the extraction of trichloromethane and tribromomethane from treated water sample are $96 \pm 0.70$ and $60 \pm 2.82 \%$, respectively. Tribromomethane percentage recovery from raw water sample was $95 \pm 1.21 \%$ while the percentage recovery of Trichloromethane from the raw water sample was $96 \pm 1.41 \%$. However, in order to validate the extraction process, the deionized water, which represents blank sample, was also spiked with a known concentration of trichloromethane and tribromomethane, and the recovery percentages after the extraction process for the two THMs were $100 \%$, respectively. According to Reckhow and Ndabigengesere et al. $[19,20]$, recovery percentage yields of 100 and $90 \%$ are considered to be qualitative and excellent yield, $50-80 \%$ are considered to be good yield while $40 \%$ below are considered to be poor yield.

3.10. Adsorption Isotherms. The results of the sorption ability of Moringa oleifera seed husk activated carbon as natural adsorbent were evaluated through determination of adsorption isotherm of trichloromethane and tribromomethane sorption system and are presented in Figures 7(a) and 7(b) (Langmuir isotherm) and Figures 8(a) and 8 (b) (Freundlich isotherm) while Table 7 shows the coefficients of these isotherms (Langmuir and Freundlich). The results show that the adsorption process is suitable well with Langmuir than Freundlich isotherms.

\section{Conclusion}

The study concluded that the concentrations of 0.5395 and $0.5725 \mathrm{mg} / \mathrm{L}$ as well as 0.255 and $0.288 \mathrm{mg} / \mathrm{L}$ of trichloromethane and tribromomethane were present in the raw and treated water, respectively, from the water supply plant. The Moringa oleifera seed husk (MOSH) activated carbon produced in a one stage simple procedure at $650^{\circ} \mathrm{C}$ was $100 \%$ efficient for the removal of trihalomethanes. The optimum conditions that gave the highest efficiency for both trichloromethane and tribromomethane in this study are concentration of $0.6 \mathrm{mg} / \mathrm{l}$, adsorbent dosage of $0.8 \mathrm{~g}$, contact time of 60 minutes, and $\mathrm{pH}$ of $9 . \mathrm{MOSH}$ activated carbon can be used as a coagulant for water treatment.

\section{Recommendation/Further Work}

Water treatment plants could use activated carbon developed from the waste husk of Moringa oleifera (MO) as adsorbent before and after treatment stage in addition to the known conventional water treatment processes.

\section{Data Availability}

The data used to support the findings of this study are included within the article. 


\section{Conflicts of Interest}

The authors declare no conflicts of interest.

\section{Acknowledgments}

The authors acknowledge with gratitude SwWECh Laboratory, Institute of Ecology and Environmental Studies, Obafemi Awolowo University, Ile-Ife, Nigeria, where most of the field and laboratory analyses were carried out.

\section{References}

[1] M. Sulyman, J. Namiesnik, and A. Gierak, "Low-cost adsorbents derived from agricultural by-products/wastes for enhancing contaminant uptakes from wastewater: a review," Polish Journal of Environmental Studies, vol. 26, no. 2, pp. 479-510, 2017.

[2] Y. Dai, Q. Sun, W. Wang et al., "Utilizations of agricultural waste as adsorbent for the removal of contaminants: a review," Chemosphere, vol. 211, pp. 235-253, 2018.

[3] J. N. Egila, B. E. N. Dauda, Y. A. Iyaka, and T. Jimoh, "Agricultural waste as a low cost adsorbent for heavy metal removal from wastewater," International Journal of the Physical Sciences, vol. 6, no. 8, pp. 2152-2157, 2017.

[4] J. O. Popoola and O. O. Obembe, "Local knowledge, use pattern and geographical distribution of Moringa oleifera Lam. (Moringaceae) in Nigeria," Journal of Ethnopharmacology, vol. 150, no. 2, pp. 682-691, 2013.

[5] B. Sivasankari, M. Anandharaj, and P. Gunasekaran, "An ethnobotanical study of indigenous knowledge on medicinal plants used by the village peoples of Thoppampatti, Dindigul district, Tamilnadu, India," Journal of Ethnopharmacology, vol. 153, no. 2, pp. 408-423, 2014.

[6] S. J. T. Pollard, F. E. Thompson, and G. L. McConnachie, "Microporous carbons from Moringa oleifera husks for water purification in less developed countries," Water Research, vol. 29, no. 1, pp. 337-347, 1995.

[7] Standards Organisation of Nigeria (SON), "Nigerian standard for drinking water quality," Nigerian Industrial Standard NIS, vol. 554, 2007.

[8] N. A. Salem and S. M. Yakoot, "Non-steroidal anti-inflammatory drug, ibuprofen adsorption using rice straw based biochar," International Journal of Pharmacology, vol. 12, no. 7, pp. 729-736, 2016.

[9] Y. Shang, J. Zhang, X. Wang et al., "Use of polyethyleneiminemodified wheat straw for adsorption of Congo red from solution in batch mode," Desalination and Water Treatment, vol. 57, no. 19, pp. 8872-8883, 2015.

[10] N. Rattanachueskul, A. Saning, S. Kaowphong, N. Chumha, and L. Chuenchom, "Magnetic carbon composites with a hierarchical structure for adsorption of tetracycline, prepared from sugarcane bagasse via hydrothermal carbonization coupled with simple heat treatment process," Bioresources Technology, vol. 226, pp. 164-172, 2016.

[11] H. Gupta and B. Gupta, "Adsorption of polycyclic aromatic hydrocarbons on banana peel activated carbon," Desalination and Water Treatment, vol. 57, no. 20, pp. 9498-9509, 2015.

[12] R. Tang, C. Dai, C. Li, W. Liu, S. Gao, and C. Wang, "Removal of methylene blue from aqueous solution using agricultural residue walnut shell: equilibrium, kinetic, and thermodynamic studies," Journal of Chemistry, vol. 2017, Article ID 8404965, 10 pages, 2017.
[13] C. Tang, Y. Shu, R. Zhang et al., "Comparison of the removal and adsorption mechanisms of cadmium and lead from aqueous solution by activated carbons prepared from Typha angustifolia and Salix matsudana," RSC Advances, vol. 7, no. 26, pp. 16092-16103, 2017.

[14] A. Okoya, A. Akinyele, O. Amuda, and I. Ofoezie, "Chitosangrafted carbon for the sequestration of heavy metals in aqueous solution," American Chemical Science Journal, vol. 11, no. 3, pp. 1-14, 2016.

[15] A. M. Warhurst, G. L. McConnachie, and S. J. T. Pollard, "Characterisation and applications of activated carbon produced from Moringa oleifera seed husks by single-step steam pyrolysis," Water Research, vol. 31, no. 4, pp. 759-766, 1997.

[16] T. A. H. Nguyen, H. H. Ngo, W. S. Guo et al., "Applicability of agricultural waste and by-products for adsorptive removal of heavy metals from wastewater," Bioresource Technology, vol. 148, pp. 574-585, 2013.

[17] A. W. Morawski and M. Inagaki, "Application of modified synthetic carbon for adsorption of trihalomethanes (THMs) from water," Desalination, vol. 114, no. 1, pp. 23-27, 1997.

[18] M. Samadi, S. Nasseri, A. Mesdaghinia, and M. Alizadefard, "Removal of chloroform $\left(\mathrm{CHCl}_{3}\right)$ from tehran drinking water by GAC and air stripping columns," Iranian Journal of Environmental Health Science Engineering, vol. 1, no. 1, pp. 5-12, 2004.

[19] D. A. Reckhow, Analysis of Trihalomethanes and Related Pentane-Extractable Organic Halides, University of Massachusetts, Amherst, MA, USA, 2012, http://www.ecs.umass. edu/eve/research/sop/THM.pdf.

[20] A. Ndabigengesere, K. S. Narasiah, and B. G. Talbot, “Active agents and mechanism of coagulation of turbid waters using Moringa Oleifera," Water Research, vol. 29, no. 2, pp. 703-710, 1995.

[21] T. Okuda, A. U. Baes, W. Nishijima, and M. Okada, "Improvement of extraction method of coagulation active components from Moringa oleifera seed," Water Research, vol. 33, no. 1, pp. 3373-3378, 1999.

[22] O. S. Fatoki and O. R. Awofolu, "Methods for selective determination of persistent organochlorine pesticide residues in water and sediment by capillary gas chromatography and electron capture detector," Journal of Chromatography A, vol. 983, no. 1-2, pp. 225-236, 2003.

[23] A. A. Okoya, N. Torto, A. O. Ogunfowokan, and O. I. Asubiojo, "Organochlorine pesticides (OCP) residues in soils of major cocoa plantation in ondo state, south western Nigeria," African Journal of Agricultural Research, vol. 8, no. 28 , pp. 3842-3848, 2013.

[24] Standardization and Industrial Research Institute Malaysia (SIRIM), Specification of Powdered Activated Carbon MS873, Standardization and Industrial Research Institute Malaysia (SIRIM),, Kuala Lumpur, Malaysia, 1984.

[25] S. T. Adewole, A. Kuku, and A. Okoya, "Efficacy of a natural coagulant protein from Moringa oleifera (Lam) seed husk in treatment of Opa reservoir water, Ile-Ife, Nigeria," Heliyon, vol. 6, no. 1, Article ID e03335, 2020.

[26] M. A. Yahya, Z. Al-Qodah, and C. W. Z. Ngah, "Agricultural bio-waste materials as potential sustainable precursors used for activated carbon production: a review," Renewable and Sustainable Energy Reviews, vol. 46, pp. 218-235, 2015.

[27] Y. Gokce and Z. Aktas, "Nitric acid modification of activated carbon produced from waste tea and adsorption of methylene blue and phenol," Applied Surface Science, vol. 313, pp. 352359, 2014. 
[28] L. M. Mataka, S. M. Sajidu, W. R. Masamba, and J. F. Mwatseteza, "Cadmium sorption by Moringa stenopetala and Moringa oleifera seed powders : batch, time, temperature, $\mathrm{pH}$ and adsorption isotherm studies," International Journal of Water Resources and Environmental Engineering, vol. 2, no. 3, pp. 50-59, 2010.

[29] S. Kamsonlian, C. Balomajumder, and S. Chand, "A Potential of biosorbent derived from banana peel for removal of as (III) from contaminated water," International Journal of Chemical Sciences and Applications, vol. 3, no. 2, pp. 269-275, 2012.

[30] K. Kairvelu, K. Thamaraiselvi, and C. Namazivayam, "Removal of heavy metals from industrial wastewaters by adsorption onto activated carbon prepared from an agricultural solid waste," Bioresources Technology, vol. 76, no. 1, pp. 63-65, 2001.

[31] H. Bakouri, J. Morillo, J. Usero, and A. Ouassini, "Natural attenuation of pesticide water contamination by using ecological adsorbents: application for chlorinated pesticides included in European water framework directive," Journal of Hydrology, vol. 364, no. 1-2, pp. 175-181, 2009.

[32] C. Lu, Y. Chung, and K. Chang, "Adsorption thermodynamic and kinetic studies of trihalomethanes on multiwalled carbon nanotubes," Journal of Hazardous Materials, vol. 138, no. 2, pp. 304-310, 2006.

[33] A. A. Okoya, O. S. Adegbaju, O. E. Akinola, A. B. Akinyele, and O. S. Amuda, "Comparative assessment of the efficiency of rice husk biochar and conventional water treatment method to remove chlorpyrifos from pesticide polluted water," Current Journal of Applied Science and Technology, vol. 39 , no. 2, pp. 1-11, 2020.

[34] G. Z. Memon, M. I. Bhanger, M. Akhtar, F. N. Talpur, and J. R. Memon, "Adsorption of methyl parathion pesticide from water using watermelon peels as a low cost adsorbent," Chemical Engineering Journal, vol. 138, no. 1-3, pp. 616-621, 2008. 